European journal of American studies

Special Issue of the European Journal of American

Studies: Cormac McCarthy Between Worlds

\title{
The Tennis Shoe Army and Leviathan: Relics and Specters of Big Government in The Road
}

\section{Robert Pirro}

\section{(2) OpenEdition \\ Journals}

Electronic version

URL: https://journals.openedition.org/ejas/12285

DOI: $10.4000 /$ ejas. 12285

ISSN: 1991-9336

Publisher

European Association for American Studies

Electronic reference

Robert Pirro, "The Tennis Shoe Army and Leviathan: Relics and Specters of Big Government in The Road", European journal of American studies [Online], 12-3 | 2017, Online since 18 December 2017, connection on 08 July 2021. URL: http://journals.openedition.org/ejas/12285 ; DOI: https://doi.org/ 10.4000/ejas. 12285

This text was automatically generated on 8 July 2021 .

Creative Commons License 


\title{
The Tennis Shoe Army and Leviathan: Relics and Specters of Big Government in The Road
}

\author{
Robert Pirro
}

political reticence of Cormac McCarthy's 2006 novel The Road differentiates it from other post-apocalyptic works. While works in this genre imagine life after the breakdown of civilization and the collapse of political order, the scenarios they narrate usually offer abundant evidence of the influence of political events and ideas or the traces of a political point of view. In some cases, authors or filmmakers directly testify to the influence of politics on narrative themes as when filmmaker George Romero, taking note of the student protest movements and inner city riots going on during the making of Night of the Living Dead (1968), asserted that his path-breaking zombie film was about revolution (Romero in Kuhns). Even without such direct testimony, the fact that works of post-apocalyptic literature and film often proliferate in the wake of, and in seeming response to, major political events and developments suggests how such works can come to be infused with political meaning. Along these lines, an observer of the Arab literary scene of the last several years recently noted that, "a new wave of dystopian and surrealist fiction" has been building among "Middle Eastern writers who are grappling with the chaotic aftermath and stinging disappointments of the Arab Spring" (Alter). Citing one Egyptian editor's view that "futuristic stories are all about lost utopia," an observer of this trend noted that, "in the months after the uprisings, some novelists channeled their frustrations and fears into grim apocalyptic tales" (Alter).

In many instances, post-apocalyptic stories include hindsight reflections on how political institutions directly contributed to, or failed to prevent, the state of civilizational collapse they narrate. So, for example, the protagonist of Richard Matheson's I am Legend (1954), reduced to relying on his own ingenuity to survive in an environment of nightly threat, refers repeatedly to the failure of public authorities to 
recognize and effectively respond to initial manifestations of the plague of vampirism whose progress would eventually result in complete societal breakdown. Oftentimes, the collapse of conventional political authorities in post-apocalyptic stories occasions the creation of new political relationships and institutions, as when the protagonists of John Wyndham's 1951 novel The Day of the Triffids find themselves threatened by an authoritarian organization engaged in press-ganging survivors of the triffid invasion into rigidly supervised farm camps.

In contrast to the relative transparency of political influences and meanings on offer in many post-apocalyptic texts, The Road remains, for the most part, politically opaque. Obvious references to political values, practices, organizations, or institutions are almost completely lacking. While the narrative of The Road is premised on a previous breakdown of governmental institutions and conventional political identities, the reader is not apprised of how that breakdown occurred or even whether politics had a role in the advent of a catastrophe whose causes McCarthy leaves unexplained. The action of the novel starts in a condition of complete governmental absence, after food production has come to a standstill and a much reduced population is reduced to scavenging scattered and ever more depleted food stocks left over from pre-apocalyptic times. The rudimentary forms of collective organization-e.g., "blood cults" (16), "communes" (79)-that arose in the immediate aftermath of the catastrophe have, by the time of the events recounted in The Road, mostly disappeared, leaving only scattered refugees and roving bands of slavers and cannibals.

5 The scale of resource deprivation in The Road sets it apart from many other postapocalyptic novels in which new forms of political solidarity based on charismatic leaders or bureaucratic organizations emerge in one form or another. The extremities to which the novel's protagonists are driven to find food have led Simon Schleusener to characterize The Road as partaking in a radically dystopian mood in which utopian alternatives to the neoliberal world order are less and less conceivable. Far from pointing the way toward alternatives to capitalism, the novel, in his view, merely extends and intensifies the dog-eat-dog world of capitalist exchange and reflects how much easier it is these days to imagine the end of the world than to imagine the end of capitalism (Schleusener).

6 For his part, McCarthy has given no direct indication that his post-apocalyptic novel originates in a sense of disappointment or despair about capitalism or about politics of any sort. He did report during his interview with Oprah that the idea for the book came to him late one night when he was checked into a hotel in El Paso with his young son. Looking out over the city, he envisioned hills on fire and began to imagine what El Paso would look like in fifty or a hundred years. Perhaps with thoughts of political context in mind, Dianne Luce, in a 2008 publication, situated that instance of creative inspiration "perhaps not long after September 11, 2001" ("Beyond the Border" 9). Based on the testimony of McCarthy's third wife about the conversations she and McCarthy were having in the aftermath of the 9/11 attacks, Luce has become more confident that anxieties aroused by the terrorist attacks formed an important emotional context for the composition of The Road ("Projecting Interiority").

7 This article initially approaches the question of the possible political sources and meanings of The Road along a couple of theoretical avenues: social contract theory's postulate of a pre-political, pre-governmental state of nature and an Emersonianderived theory of how poetic attachment to the world can foster support for 
democratic self-government. As it will turn out, neither avenue leads to a perspective on the novel that convincingly reveals a novelistic ambition to engage with political ideas or re-envision political order. As will be shown, the novel's reticence is consistent with the expressions of skepticism about the use or worth of government that appear in several of McCarthy's earlier novels. Returning to the text of The Road, this article reconsiders the few explicit mentions of governmental institutions to suggest the working of a basic skepticism about large-scale, bureaucratically organized governments. That skepticism will find its most emotionally powerful expression in the nightmarish appearance of "an army in tennis shoes, tramping" (91), whose significance is vouchsafed by McCarthy's tendency in earlier novels to deploy imaginary processions as a way of revealing a protagonist's inner preoccupations and whose negative valence is confirmed by its resemblances to Hobbes's image of the artificial Leviathan as a machinery of domination.

\section{Traces of Politics and Political Thought in The Road}

8 To the extent that The Road is set in a time long after the end of government and when the struggle for food among scattered human survivors is of overwhelming urgency, political institutions or relationships are not a factor in the story. This is particularly so because of the nature of the one relationship around which the narrative is exclusively focused, the relationship between a father and his pre-adolescent son who, at the margins of survival, make their way through a ravaged and lawless landscape. With a very few exceptions, as when the father, consulting a "tattered oil company roadmap" with his son, explains that "state roads" belonged to what used to be states (43), political terminology is absent from the text and political ideas are not a subject of conversation between the two. This is not to say that political meanings are impossible to find in a narrative so bereft of obvious political references. One might, for example, draw an analogy between the post-apocalyptic setting of The Road and the state of nature, the imagined condition of complete governmental absence envisioned by social contract theorists such as Hobbes, Locke, and Rousseau.

In imagining states of nature, theorists in the social contract tradition can be seen as indirectly commenting on what they think people owe to government. On this reading, a theorist's vision of the appropriate structure and reach of government influences his depiction of the conditions that hold in a state of nature. The more extreme and inhumane the conditions are in the depiction of life in the absence of government, the greater the claim that governments can make on their citizens to accept the limits and inconveniences of life in a politically ordered society. This logic would explain why Hobbes, who of all the classic social contract thinkers offers the most grim picture of life without government-he describes it succinctly as "solitary, poore, nasty, brutish, and short" (186)-endorses the most authoritarian government, whose all-powerful sovereign enjoys robust powers of indoctrination and repression.

The extremities to which the characters of The Road are driven in the absence of any governmental order invite comparisons between the post-apocalyptic conditions of The Road and Hobbes's depiction of the natural condition of mankind in his theoretical masterpiece, Leviathan. For literary theorist Eva Horn, author of Zukunft als Katastrophe [The Future as Catastrophe] (2014), The Road poses a fundamental question-What happens to human beings in the wake of a disaster that ends most animal and plant life 
on earth?-and offers the gloomy answer: "When man is put under pressure, he reveals himself to be a pretty bad type, cruel, egoistic, brutal" (Stallknecht; my translation). McCarthy may even be referencing Hobbes in the opening page of his novel, when the father wakes from a dream in which he and his son encounter a subterranean beast on the banks of a "black and ancient lake"; the creature "swung its head low over the water as if to take the scent of what it could not see" (4). It was, after all, a beast of the nether regions that inspired-via the Old Testament story of Job-the title of Hobbes's book.

11 In the Book of Job, God evokes the power of the sea monster Leviathan as a way of extinguishing Job's impertinence and of teaching him never again to demand a divine explanation for human suffering. Hobbes quotes from the biblical verse (Job 38: 4) that commences God's reproach of human impertinence by way of explaining how superior power justifies rulership:

12 And Job how earnestly does he expostulate with God, for the many Afflictions he suffered, notwithstanding his Righteousness? This question in the case of Job, is decided by God himselfe, not by arguments derived from Job's Sinne, but his own Power. For whereas the friends of Job drew their arguments from his Affliction to his Sinne, and he defended himselfe by the conscience of his Innocence, God himselfe taketh up the matter, and having justified the Affliction by arguments drawn from his Power, such as this, Where wast thou when I layd the foundations of the earth[.] (398; original italics)

Starting with a rhetorical question pointing out humanity's absence at the creation, the biblical passage continues with a series of questions designed to impress upon Job his relative insignificance in the face of God's omnipotence. Culminating this tirade, God evokes a sea monster: "Canst thou draw out Leviathan with a fish-hook? / Or press down his tongue with a cord? / Or bore his jaw with a hook? / Will he make supplications unto thee?" (Jacobson 52-53).

Watching from a safe distance the breakdown of order and proliferation of violence during the English Civil War, Hobbes hoped for a Book-of-Job-like effect from the authoritarian body politic he imagined as a stable replacement for an English monarchy that had not shown itself up to the task of keeping Englishmen loyal and law-abiding. Members of this political construct would be so awed by its power that they would have little thought to resist, or even complain about, its acts of government. And that would ultimately be for the best for the vast majority of Leviathan's citizens because life in the Leviathan despite its mostly small inconveniences is so much more acceptable than life in the state of nature.

Complicating the supposition of Hobbesian influence on McCarthy is the fact that the creature of the father's dream in the opening pages of The Road is far from being the awesome and imposing force of nature evoked in the Old Testament story of Job and appropriated by Hobbes. It is, rather, a pathetic creature of darkness who flees at the scent of humans. Behind this dream image, one detects little of the political theoretical ambition of Hobbes who thought so intensively and comprehensively about the nature and significance of governance. McCarthy certainly has never pretended to be a political theorist of the sort Hobbes was. However, there are other kinds of political theory to which we might profitably relate McCarthy, theories that are less explicit about their political ambitions and less obviously concerned with offering a blueprint for constructing a new political order. McCarthy gives a hint of his possible affiliation with a more subtle and indirect political theoretical tradition in his 1985 novel, Blood 
Meridian, where he resorts to specialized political vocabulary in a decidedly apolitical setting. In the scene in question, the members of the murderous Anglo raiding party makes their way through the desolate Texas Badlands. The murder gang passes by awesome geologic formations (e.g., "a vast dry lake with rows of dead volcanoes ranged beyond it like enormous insects"), encounters husks of long dead animals and the occasional human victim of interethnic or interracial strife (" $[t]$ he mummified corpse hung from the crosstree, a thing of leather and bone scoured by the pumice winds off the lake"), and tramps across parched ground raising whorls of dust that make it seem "as if the very sediment of things contained yet some residue of sentience" (258). To characterize that biologically hostile, yet aesthetically vital landscape, McCarthy summons language that more properly belongs to political discourse than to naturalistic description:

In the neuter austerity of that terrain all phenomena were bequeathed a strange equality and no one thing nor spider nor stone nor blade of grass could put forth claim to precedence. The very clarity of these articles belied their familiarity, for the eye predicates the whole on some feature or part and here was nothing more luminous than another and nothing more enshadowed and in the optical democracy of such landscapes all preference is made whimsical and a man and a rock become endowed with unguessed kinships. (Blood Meridian 258-259)

Passages such as these have led some commentators to suggest the working of a naturederived ethics in McCarthy's writings, a "bioethics" or "ecopastoralism" "that sees all forms of life as equal" (Georg Guillemin as cited by Palmer 63). McCarthy's description of landscape in terms of explicitly political language raises the possibility of the operation of a sensibility that political theorist George Kateb has derived in significant part from the writings of Emerson, Thoreau and Whitman and has formulated under the label, democratic individuality. Kateb argues that these exemplary American thinkers and writers recommended a way of looking at nature and at existence, more generally, in which the onlooker would attain a contemplative mood of acceptance of the endless variety and raw vitality of the phenomena of the world. For Kateb, this special kind of attentiveness to nature and the world, and the appreciation it fostered of the wonder of existence, was intended by Emerson, Thoreau, and (especially) Whitman to have political consequences for the democratic culture of representative government in the United States. In particular, they expected it to inspire a form of individuality which would be more tentative in its taking on of political identities and more playful in its social commitments and therefore especially vigilant against any absolutist claims posed by political authorities whose status is at least theoretically unsettled by periodic elections. Because this wonder at existence was believed by them to be broadly available, potentially accessible by even the most unschooled and uncultivated person, it was an individuality to which citizens of representative democracy could and should aspire. Describing the "nonhierarchical structure" of Suttree's (1979) narrative, in which, in particular scenes, "man, machine, and nature seem to be in perfect harmony in an aesthetic that is based on the relatedness of things," Guillemin links McCarthy's "ecopastoralism" to "the experience of the egalitarian nature of the universe" (16). While the characterization of McCarthy's perspective is drawn via a quotation from Walt Whitman's Specimen Days (1882), Guillemin does not draw any Katebian conclusions about the possible political valences of Suttree. 

choice to employ political theoretical terminology in evoking the vitality of the material world in Blood Meridian, there are reasons to doubt that a similar political theoretical perspective operates in the case of The Road. First, as has already been noted, there are no similar examples in this latter work of McCarthy explicitly using political language to evoke the effects of aesthetic contemplation of nature (e.g., "optical democracy"). In the second place, the landscape setting of The Road and its description of the material world lack the variety and definition that served to endow the novelistic landscapes of Blood Meridian, if not other of his novels, with vitality of the kind that might inform a political purpose. Under perennially overcast skies from which periodic flurries of ash coat the surfaces of a world increasingly featureless, it becomes harder and harder optically to appreciate contrasts and recognize the outlines of things. On one level, then, McCarthy's landscape resists interpretation, for the landscape is largely mute, darkened, clouded, its color palette stripped of beauty and diversity and reduced to variations of gray. The visionary clarity of Emerson's nature is notably absent from the blasted environment of McCarthy's world in The Road (Edwards 56-57).

In setting the action of its protagonists in this monotone and blurred landscape, The Road does not so easily invite consideration of any purported political meaning in terms of Kateb's theorization of an Emersonian political legacy. ${ }^{1}$ In general, far from being interested in politics as a literary subject, McCarthy, with a few exceptions, seems almost wholly engaged in his major writings with what one might characterize as ordinary or nonpolitical life. So, for example, one can read McCarthy's early novel Suttree as a literary refutation of the judgment offered by one of the novel's characters, Suttree's father, a man of no small experience in public affairs: "the world is run by those willing to take the responsibility for the running of it. If it is life that you feel you are missing I can tell you where to find it. In the law courts, in business, in government. There is nothing occurring in the streets. Nothing but a dumbshow composed of the helpless and the impotent" (13-14). In the course of the ensuing story, McCarthy's narrative lingers affectionately and observantly on the so-called "dumbshow," inviting attention to, if not appreciation of, the import of those very lives Suttree's father holds up for contempt. And he depicts Suttree as, according to one reader, unable or "unwilling to assume any form of civic responsibility" (Guillemin 6). If there is a fundamental contrast of views about the worth of law courts, business and government at work in the novel, it may have autobiographical roots. McCarthy's father was an attorney employed by the Tennessee Valley Authority to condemn properties in order to make way for dam construction. Luce has referred to McCarthy's resentment of the destruction of local communities wrought by the activities of the TVA and she has further suggested that he, as the son of his attorney father, may have felt that he had "inherited complicity with the TVA" ("Projecting Interiority").

Consistent with both Suttree's apparent prejudice in favor of ordinary folk living lives outside the halls of power and Luce's account of McCarthy's critical attitude toward his father's work for the government in Appalachia, the sympathetically-drawn main characters of McCarthy's first novel, The Orchard Keeper (1965), tend, in their run-ins with local authorities, to hold themselves aloof from, and morally superior to, public officials. So, for example, the welfare functions of government are held up for ridicule in the person of the handkerchief-dabbing, briefcase-carrying social worker who lacks 
the least bit of empathetic understanding of the sense of dignity and independence which motivated old man Ownby to resort to force against officers of the law coming to evict him from his mountain shack. Sitting in his cell after his capture, Ownby is put off by the visiting social worker's polite insistence on asking after Ownby's birth date and other personal information presumably to qualify him for the government assistance to which he might be entitled. Unwilling to submit himself to the form-filling protocols of the social worker, Ownby declares himself ready to serve his time at the local prison on Brushy Mountain. "You can set and ast a bunch of idjit questions. But not knowin a thing ain't never made it not so. Well, I'm a old man and I've seen some hard times, so I don't reckon Brushy Mountain'll be the worst place I was ever in" (221). Similarly, Sylder, incarcerated for attempting to smuggle liquor in a dry county, is contemptuous of the local sheriff who captured him, judging him "a traitor... who sells his own neighbors out for money and it's few who lie that deep in the pit" (215). The contrast between officialdom and populus is carried over into narrative description as when Sylder, on one of his bootleg whiskey runs, is depicted as "genial, unofficial, and awake," after he passes a military vehicle whose occupants looked "serious and official, but somewhat sleepy and not in any particular hurry" (98).

Even when McCarthy makes a public official one of his main characters and draws him sympathetically, as with Sheriff Ed Tom Bell in No Country For Old Men (2005), the office which he occupies is almost completely divested of any of the bureaucratic infrastructure which typically underpins governmental authority:

There's no requirements in the Texas State Constitution for bein a sheriff. Not a one. There is no such thing as county law. You think about a job where you have pretty much the same authority as God and there is no requirements put upon you and you are charged with preserving nonexistent laws and you tell me if that's peculiar or not. Because I say that it is. Does it work? Yes. Ninety percent of the time. It takes very little to govern good people. And bad people cant be governed at all. Or if they could I never heard of it. (64)

McCarthy's novelistic expressions of disdain for impersonal government institutions (what Max Weber identified as the bureaucratic dimension of political rule) together with the doubt voiced by his characters over the effectiveness of these institutions in the absence of self-policing citizens hints at the working of a general skepticism about governance, particularly when this governance is exercised by officeholders at some remove from the people over whom they have authority. While The Road offers no direct examples of the working of such governance, it does make brief reference to a once-existing government. That reference comes in the aforementioned scene in which the father traces out their route on an old map: "We cross a bridge here. It looks to be about eight miles or so. This is the river. Going east. We follow the road here along the eastern slope of the mountain. These are our roads, the black lines on the map. The state roads" (The Road 42). Wesley Morgan has shown that the route the father takes through a significant part of the novel is through towns and countryside with which McCarthy would have been familiar as a child growing up in the Knoxville area. One such site is the dam and lake, which the boy and his father observe from a roadside overlook. The father explains that the dam "made the lake. Before they built the dam that was just a river down there. The dam used the water that ran through it to turn big fans called turbines that would generate electricity" (19-20). 
Morgan identifies the site as Norris Dam, "the first built by the Tennessee Valley Association [sic] completed in 1936 to provide flood control and recreation, and to generate power" (40). Later, the boy and his father arrive at the parking lot of another overlook, this one, Morgan tells us, of the Newfound Gap in the Great Smoky Mountains National Park. It was at this parking lot on Labor Day 1940 that FDR dedicated the park (43). Possible reference is also made during the odyssey of the boy and his father to an area of land which "during the period 1950-1951 the federal government condemned or bought for the Savannah River project," a program that resulted in the construction of a reactor complex for the production of weapon grade nuclear materials (Morgan 45).

Dam building, national parks designations, and nuclear weapons development constituted high profile activities of an activist federal government in the twentieth century, beginning with Teddy Roosevelt's establishment between 1901 and 1909 of five new national parks as well as his signing an Antiquities Act (1906) that empowered presidents to establish national monuments on public lands containing sites of particular historic or scientific interest. Dam building was a crucial component of the public works program of the New Deal government of President Franklin Roosevelt, aimed at stimulating the economy through jobs creation and raising living standards through electrification. The 1950s Savannah River project was a direct heir of the 1940s Manhattan Project, the first mega-investment by the US government in nuclear weapons development. While the pair make their way mainly along "state" roads, they do occasionally encounter interstate exchanges whose construction would have been authorized by another big ticket federal program, the Federal Aid Highway Act signed by President Eisenhower in 1956.

Is McCarthy's choice of the pair's stops at historically resonant places intended to make a political point? To the extent that these are sites of immense and ultimately successful governmental effort, they stand in clear and obvious contrast to the catastrophic condition of governmental absence in which the boy and his father find themselves. To be sure, the father does not indicate any knowledge of, nor volunteer any background information on, the contribution of governmental activity to the development of these sites. The builders of the dam are a nondescript "they." What is emphasized is the durability of these human constructions. In response to the son asking, "Will the dam be there for a long time?" the father answers, "I think so. It's made out of concrete. It will probably be there for hundreds of years. Thousands, even" (The Road 20). In their later back-and-forth about state roads, the notion of durability is again evoked:

But there's not any more states?

No.

What happened to them?

I don't know exactly. That's a good question.

But the roads are still there.

Yes. For a while.

How long a while?

I don't know. Maybe quite a while. There's nothing to uproot them so they should be okay for a while. (43)

If irony is intended with these references to the durability of large scale human constructions that will long outlast their utility, it is not clear whether the critique is narrowly political (directed at governments that undertake such infrastructure projects) or more broadly existential (directed at human beings' tendency to overlook 
the fragile bases of human life on this planet). Supporting an ironic reading of these passages, Linda Woodson characterizes these infrastructure projects as "signifiers with no signified" and relates The Road to postmodernism's questioning of "the role of language accurately to represent reality" $(92,90)$.

Morgan suggests that the selection of these sites for narrative use in The Road was influenced by McCarthy's memories of his own childhood visits. Assuming that these visits to sites of enormous government expenditure and local community dislocation were led by McCarthy's father, one wonders what meaning these occasions held for McCarthy as a boy. Did his father express pride in pointing out infrastructure projects, some of which he may personally have had a hand in? Either at the time of the visits, or later, McCarthy would have been or become aware of the human costs of those projects to the communities whose lands were taken. The boy in The Road wants to linger at what Morgan identifies as the Norris Dam, but the father refuses out of concern about being surprised by the arrival of other stragglers or worse.

By itself, the overlap of stops by father and son on their desperate trek to the sea and encounters with massive but now obsolete government infrastructure projects is far from being definitive evidence of the working of a critique of big government in McCarthy's text. However, when considered beside an instance in the text of what can plausibly be read as a grotesque parody of political organization, this overlap carries greater interpretive weight. This instance happens at a time when father and son are out of food. After a futile search through a crumbling mill town, the pair pass by a stone wall in the countryside topped by the decorated skulls of the losers of some past skirmish between cannibal bands. Camped nearby, the father awakes the next morning to see the approach of "an army in tennis shoes, tramping" (The Road 91). Remaining prone and keeping his son's head down, he watches what turns out to be a highly organized group of people march by. In the vanguard are two units of fighters, "dressed in clothing of every description [but] all wearing red scarves at their necks," the first carrying maces, the second, a "phalanx," bearing makeshift spears and lances. They march four abreast "with a swaying gait like wind-up toys." Next, "slaves in harness" drag wagons "piled with goods." Following after are "the women, perhaps a dozen in number, some of them pregnant, and lastly a supplementary consort of catamites illclothed against the cold and fitted in dogcollars and yoked to each other" (92).

The image is striking for a number of reasons. It is the largest conglomeration of people that the boy and his father come across. It is so large (at least several dozen to judge from the description of its various components), one wonders how this concentration of people could be provisioned in a landscape described as being "rifled of every crumb" (129). As the tennis shoe army processes by, no indication is given of a directing presence or authority, which raises the further question of how the order and discipline of the group is maintained. And would it make sense for people on a caloriepoor diet to be expending so much energy marching with a gusto that causes, from a distance of two hundred feet "the ground [to] shudder slightly" (92) when potential enemies or food sources are nowhere in evidence?

31 The lack of realism in McCarthy's depiction of this "army" becomes more conspicuous on a comparison of it with the ragtag band of armed scavengers traveling on foot and by truck, one of whose members fatally encounters the father. These men, "stained and filthy," "shuffle through the ash" and "slouch along" (60). The scavenger who stumbles upon the father and son while looking for a place to defecate, shows "the progress of 
his emaciation" in the worn holes of his belt (63). The depiction of these wandering ragged brigands is much more consonant with the conditions of life established by the narrative. In addition, the encounter with this band furthers the action of the plot in a realistic way. By contrast, the tennis shoe army appears, in this impoverished landscape, as a larger-than-life spectacle with no discernible effect on plot development.

One possible way to account for the tennis shoe army's fleeting appearance is as a hallucination of the father. After all, the narrative gives no indication that the only other possible witness to the phenomenon, the boy, sees or hears this nightmare procession. His father presses the back of his head so that he remains face down for the duration. And all of the boy's questions can be read as solely responding to the father's actions rather than to an independently occurring event.

There are precedents in McCarthy's writings of hallucinatory imaginings of fleeting processions and strange parades of humanity. Take, for example, the vision that the main character of Suttree has after weeks of solitary wandering across unpopulated mountain forests in a state of severe malnourishment. The narrative makes plain Suttree's loose grip on reality with several references to his perception of ghostly presences in the mountain stillness. Then, one night, as a thunderstorm blows through, he has a vision: "Suttree heard laughter and sounds of carnival. He saw with a madman's clarity the perishability of his flesh. Illbedowered harlots were calling from small porches in the night, in their gaudy rags like dolls panoplied out of a dirty dream" (Suttree 287). The harlots are followed by, in turn, "trolls," "an aldern gnome," "a piper," " a mesosaur," and "a gross and blueblack foetus," among other fantastical creatures (278). Guillemin considers this episode exemplary of McCarthy's "parabolic" storytelling, akin to the "realism Mikhail Bakhtin has defined as carnivalesque" (10). Comparing the hallucinatory mountain parade to "Shakespeare's Midsummer Night's Dream, Goethe's Faust II, or the tableaux of Hieronymous Bosch," Guillemin goes on to argue for McCarthy's tendency to muster narrative energy through the use of grotesque imagery (10).

One can counterpose Suttree's hallucinatory vision of a parade of mythic or grotesque creatures to the realistic portrayal of a religious procession in Blood Meridian. On the day of the feast of Las Animas in the frontier town of Jesús María, members of Glanton's murder gang, including the kid and the judge, witness a procession. "It is led by a horsedrawn cart that bore a rude Christ in a stained and ancient catafalque. Lay acolytes followed all in company and the priest went before ringing a small bell. A barefoot brotherhood clad in black marched in the rear bearing scepters of weeds. The Christ jostled past, a poor figure of straw with carven head and feet. He wore a crown of mountain briars and on his brow were painted drops of blood and on his old dry wooden cheeks blue tears" (199).

Villagers respond to the religious procession in the expected way, kneeling, crossing themselves, and reaching for fleeting contact with the Christ figure. In important respects, this scene anticipates another religious procession which appears to the kid years later, after the break-up of the murder gang. After years of desultory work accompanying wagon trains in California, the kid abandons a party of migrants at a desert well seven days march from the coast. In a trackless area of mountain wastes, he unexpectedly encounters "men who seemed unable to abide the silence of the world" (326): 
He first saw them laboring over the plain in the dusk among the flowering ocotillo that burned in the final light like horned candelabra. They were led by a pitero piping a reed and then in procession a clanging of tambourines and matracas and men naked to the waste in black capes and hoods who flailed themselves with whips of braided yucca and men who bore on their naked backs great loads of cholla and a man tied to a rope who was pulled this way and that by his companions and a hooded man in a white robe who bore a heavy wooden cross on his shoulders. They were all of them barefoot and they left a trail of blood across the rocks and they were followed by a rude carreta in which sat a carved wooden skeleton who rattled along stiffly holding before him a bow and arrow. He shared his cart with a load of stones and they went trundling over the rocks drawn by ropes tied to the heads and ankles of the bearers and accompanied by a deputation of women who carried small desert flowers in their folded hands or torches of sotol or primitive lanterns of pierced tin. (326)

While this latter procession shares religious imagery with the procession in Jesús María, it is more drastic and less plausible in its manifestation. Its improbable appearance in a desolate landscape and its offstage transformation into a tableaux of massacre (the next morning the kid catches up to "the company of penitents... hacked and butchered among the stones in every attitude" [327]) invite questions about whether the procession is a figment of the kid's disturbed imagination. He is, after all, the sole witness to this apparition. In more than this regard, the desert procession resembles the tennis shoe army of The Road. Not only are both composed of groups differentiated by costume, equipment and gender, but there are parallels in narrative details. So, for example, the "whips of braided yucca" resemble the nunchuk-like weapons of the first phalanx of the tennis shoe army, "pipes threaded through with lengths of chain fitted at their ends with every manner of bludgeon" (91). And just as piercing weapons are the equipment of the second phalanx, the desert procession's penitents include men who carry prickly loads of spiny cactus ("cholla"). Both processions also feature deputations of women, as well as wagons drawn by humans in harness.

What might these drastic spectacles of columns of people organized in functionallydifferentiated units symbolize? If one might plausibly read the desert procession as representative of a particularly archaic, if not syncretic, form of Christianity, in which notions of sin (self-flailing penitents), death (skeleton), sacrifice (hooded man), and regeneration (women) find allegorical expression, what of the tennis shoe army? The division of labor manifested in its parade organization-common defense (phalanx), material provision (goods wagons), enforcement of social inequality (slaves), organization of sexual access (women, catamites)-mirrors, in some important respects, a body politic, three of whose vital functions are common defense, enforcement of order, and revenue collection. If the procession can be taken as an image of a body politic, the image is, arguably, a parodical one. The travesty represented by this community includes the fact that its instrument of common defense cannibalizes its defeated enemies. Slavery is practiced and a stable of women is kept. Most striking of all is the description of the "supplementary consort of catamites" whose utter debasement is registered by their being "fitted in dogcollars," an image borrowed, one imagines, from some seventies cliché of S \& M practices. Or might the relevant cultural references be Western orientalist stereotypes of Ottoman or Middle Eastern society as composed of exotic and/or threatening groups, including jannisaries, harems, and pederastic Arabs? If the latter, then Luce may be on to something with her 
claim that the 9/11 attacks were a significant context inspiring the creation of The Road. Supporting this notion of a link between 9/11 and McCarthy's book, Alan Gibbs has called attention to parallels between the tone sounded by McCarthy's story of a despairing father who resolutely resorts to any and all means in defending his son and the post-9/11 construction of America as a victim entitled to adopt any means, even the most immoral (e.g., torture), in pursuit of what it deems to be necessary for its defense. That this procession is a nightmare image of the threats the pair face in this postapocalyptic world is suggested by the parallel between the wind-up toy penguin of the bad dream related by the boy to his father earlier in their travels-"And we were in that house that we used to live in and it came around the corner but nobody had wound it up and it was really scary" (36)-and the tennis shoe army, which "clanked past, marching with a swaying gait like wind-up toys" (91). That this is the nightmare of the father, in particular, is indicated not only by the fact that he is the sole witness to the spectacle but also by the narrative's conspicuous focus on the debasement of the sexually enslaved boys. Even as he spares his son this particular vision of the father's greatest fear, he can't help but linger (as one does in a nightmare) on its minor but telling details (i.e., the use of dog collars).

To the extent that the description of the tennis shoe army is not realistic within the terms set by the narrative, the question arises as to what kind of meaning it might hold. Guillemin has argued that the "secret of McCarthy's symbolism is that it works not symbolically but allegorically" (10). In his analysis of The Road in terms of allegory - "the allegorical character is not a mimetic representation of a human being, but a personified complex of signs bearing iconographical meaning for the culturally initiated" (112) -John Vanderheide considers the tennis shoe army an example of allegorical daemonism in counterposition to the allegorical daemonism of the father (111). Vanderheide adopts this notion from Angus Fletcher to describe single-minded and obsessive agency of a kind and degree that suggests the influence of an external power, a "'foreign force, something outside the ego"' (111). This notion captures well the father's exclusive, unconditional and absolute care for his son's safety. It would also account for the tennis shoe army's seemingly leaderless but grimly purposeful passage through the landscape.

Interestingly, Vanderheide finds an archetype of allegorical daemonism in the Book of Job: "In the Book of Job... a total monotheism has definitively superseded the theological dualism of Babylonian cosmology. As this monotheism piously attributes the world's evil to God as much as it does the world's good, it also revalues Leviathan as something like God's will to destruction" (113). Vanderheide draws upon David Wolfers's interpretation of the confrontation of Job with God as a lesson in how to transcend an obsessive and ultimately self-destructive adherence to a covenantal relationship with God in favor of an understanding of Creation as without a center and open to human choice. Vanderheide's reading of the father as a Joban figure who moves from a stubborn insistence that God justify human suffering-"Are you there? he whispered. Will I see you at last? Have you a neck by which to throttle you?"-to recognition of "the peril of trucking with the emissaries of an absolute will to nothingness" (118) is highly plausible. Plausible also is his casting of the tennis shoe army as an avatar of Leviathan. This latter move is interesting from our point of view insofar as it invites reconsideration of The Road in terms of Hobbes's reading of the old Testament Leviathan as an illustration of the necessity of reducing men's pride to the 
point where they would never think to question the necessity of governmental order and social stability.

41 In my earlier consideration of the possible relevance of Hobbes's Leviathan to The Road, I noted how both works similarly evoke the utter misery of life in the absence of government. However, whereas Hobbes poses the state of nature as an argument for establishing a Leviathan-like governmental order, no similar political ambition is in evidence in McCarthy's novel. Recognizing the elements of parody in McCarthy's presentation of the tennis shoe army raises the possibility that political critique rather than political construction is in operation in The Road. The target to which that critique might be aimed becomes clearer on a recognition of a parallel that can be drawn between Hobbes's Leviathan and the tennis shoe army. McCarthy's description of that "army" in the image of wind-up toys recalls Hobbes's description of his body politic as a kind of "automata (engines that move themselves by springs and wheels as doth a watch)" (81). Referring in his book's introduction to the Leviathan as an "artificial man," Hobbes goes on to differentiate the functions and functionaries of the body politics in a way not entirely dissimilar from the father's witness of the components of that nightmare column of cannibal soldiers and debased slaves: "the magistrates and other officers of judicature and executives, artificial joints; reward and punishment, by which fastened to the seat of sovereignty every joint and member is moved to perform his duty, are the nerves, that do the same in the body natural" (81; original italics).

Based on this evidence, we raise the possibility that the authoritarian Leviathan Hobbes proposes as a solution to the misery of the state of nature makes an appearance in The Road as a parody or travesty in the form of the tennis shoe army, a cannibalistic enslavement machine bent on instrumentalizing any people it can get in its grasp. Its organizational specialization, complexity, and esprit de corps differentiate it from the other "bad guys" of The Road, the cannibalistic manor dwellers, for example, or the cannibalistic road brigands, or even the refugee trio who eat a newborn. Unlike these more informal groups, the tennis shoe army has institutionalized the practices of cannibalism and slavery in way that multiplies its power and potential reach. It is worth considering to what extent the horror of the spectacle of this army inheres not only in its monstrous practices, but also in its institutionalization of a seemingly impersonal power that seems so at odds with the reciprocal, personal care which holds the father-son dyad together. The Hobbesian Leviathan, on this view, does not get us out of the state of nature; it is the state of nature made worse. Recalling the link Gibbs establishes between the mentality of the father and the attitude of victimization and punitive vengeance evoked in Americans in the aftermath of 9/11, one might say that the lesson to draw from the tennis shoe army is that even when an act of terrorism persuades us to give our government more leeway in defending us, the government's powers to protect us are just as likely to be transformed into means of repression turned on us. After all, the Bush Administration sought to strip U.S. citizens designated as enemy combatants of their habeas corpus rights and made the use of torture against enemies of the state an official policy.

To be sure, the influence of the events of 9/11 upon McCarthy's composition of The Road is one about which we can only speculate. And even if it is conceded that the tennis shoe army allegorically expresses a critique of government, that nightmare image belongs to a character in The Road, not necessarily to the author himself. Still, to the extent that that image and the multiple expressions of skepticism about the impersonal 
governance of officialdom expressed in other McCarthy novels suggest that the The Road is in some sort of dialogue with Hobbes's famous text, one is led to wonder whether McCarthy's political attitude incorporates very large servings of skepticism about the blessings of impersonal, bureaucratic government along the lines suggested by Sheriff Ed Tom Bell's observation that, "It takes very little to govern good people. And bad people cant be governed at all."

\section{BIBLIOGRAPHY}

Alter, Alexandra. "Bleak Fiction From Arab Spring." New York Times International Weekly. June 10, 2016. 9. Print.

Edwards, Tim. "The End of the Road: Pastoralism and the Post-Apocalyptic Wasteland of Cormac McCarthy's The Road." The Cormac McCarthy Journal 6 (2008). 53-61. Print.

Gibbs, Alan. "Things Happen to You They Happen." Crossroads and Transgressions: Cormac McCarthy Between Worlds: An International Conference." John F. Kennedy Institute, Freie Universität Berlin, July 7, 2016. Unpublished Conference Paper.

Guillemin, Georg. The Pastoral Vision of Cormac McCarthy. College Station: Texas A \& M Press, 2004. Print.

Hobbes, Thomas. Leviathan. New York: Penguin, 1981. Print.

Jacobson, Norman. Pride \& Solace: The Function and Limits of Political Theory. New York: Methuen, Inc., 1986. Print.

Kateb, George. The Inner Ocean: Individualism and Democratic Culture. Ithaca: Cornell University Press, 1994. Print.

Kuhns, Rob. Birth of the Living Dead. Documentary DVD (2013).

Luce, Dianne C. "Beyond the Border: Cormac McCarthy in the New Millennium.” The Cormac McCarthy Journal 6 (2008): 6-12. Print.

---. "Projecting Interiority: Psychogenesis and the Composition of Outer Dark." Crossroads and Transgressions: Cormac McCarthy Between Worlds: An International Conference. John F. Kennedy Institute for North American Studies, Freie Universität Berlin, July 7, 2016. Opening keynote and answers to follow-up questions.

Matheson, Richard. I am Legend (New York: TOR, 1995). Print.

McCarthy, Cormac. Blood Meridian, or the Evening Redness in the West. New York: Penguin Random House, 2001. Print.

---. No Country for Old Men. New York: Knopf, 2005. Print.

---. The Orchard Keeper. New York: Vintage, 1993. Print.

---. The Road. New York: Vintage International, 2007. Print.

---. Suttree. New York: Vintage, 1992. Print. 
Morgan, Wesley. "The Route and the Root of The Road." The Cormac McCarthy Journal 6 (2008). 3947. Print.

Palmer, Louis. "Full Circle: The Road Rewrites The Orchard Keeper." The Cormac McCarthy Journal 6 (2008). 62-68. Print.

Schleusener, Simon. "From On the Road to The Road: Cormac McCarthy, Neoliberalism, and the Dialectics of Mobility." Crossroads and Transgressions: Cormac McCarthy Between Worlds: An International Conference." John F. Kennedy Institute, Freie Universität Berlin, July 7, 2016. Unpublished Conference Paper.

Stallknecht, Michael. “Alles auf der Kippe: Ein Gespräch mit der Germanistin Eva Horn über die Lust an Krisen und Katastrophen.” Süddeutsche Zeitung (145), June 25-26, 2016, 18. Print.

Vandeheide, John. "Sighting Leviathan: Ritualism, Daemonism and the Book of Job in McCarthy's Latest Works.” The Cormac McCarthy Journal 6 (2008). 107-120. Print.

Wilhelm, Randall. “'Golden Chalice, good to house a god': Still Life in The Road.” The Cormac McCarthy Journal 6 (2008). 129-145. Print.

Woodson, Linda. “Mapping The Road in Post-Postmodernism." The Cormac McCarthy Journal 6 (2008): 87-97. Print.

Wyndham, John. The Day of the Triffids (New York: Modern Library, 2003). Print.

\section{NOTES}

1. This is not to say that distinctive and optically vivid objects are entirely lacking in The Road. Noting the novel's "littering of material objects, its broken and abandoned artifacts... shorn of their previous function in a post-apocalyptic world," Randall Wilhelm has argued for their ethical significance as still life components. Especially in the narrations of the father's meal preparations, Wilhelm sees object studies of how these forlorn artifacts of a destroyed civilization can be seen to endow human acts with a morally redemptive beauty: "There are some comparatively happy moments like this one, most significantly associated with food and still life imagery-the many small frugal repasts, the dinner of morels by the waterfall in the mountains, the can of Coke from an overturned soft drink machine, the bundles of apples and cold water deep from an untainted cistern. As ancient and medieval philosophers have argued, we apprehend the moral good through our recognition of the beautiful, and in many cases we define as food not only what we like, what we are pleased by, but also what we should like to have for ourselves, not in the materialist notion of possessing particular objects, but in admirable emulation of specific properties" (18).

\section{ABSTRACTS}

Differently than many other post-apocalyptic stories, Cormac McCarthy's The Road offers scant evidence of either the influence of political events or ideas or of an authorial ambition to 
construct a vision of political order. To the extent that parallels can be drawn between the novel's presentation of a tennis shoe army on the march, which resembles dream-like processions in other McCarthy novels, and Thomas Hobbes' vision of an absolutist government as Leviathan, this essay argues that The Road can be seen as conveying an aversion to the impersonal rule of the bureaucratic state.

INDEX

Keywords: The Road, post-apocalypse, state of nature, Leviathan, Thomas Hobbes

\section{AUTHOR}

\section{ROBERT PIRRO}

Robert Pirro is a political theorist who teaches in the Department of Political Science and International Studies at Georgia Southern University. His research interests include aesthetic politics, the politics of tragedy, and film and politics. He is the author, most recently, of Motherhood, Fatherland and Primo Levi: The Hidden Groundwork of Agency in his Auschwitz Writings (2017). 